9 Darmanata JI, van Zandwijk N, Duren DR, et al. Amiodarone pneumonitis: three further cases with a review of published reports. Thorax 1984;39:57-64.

10 Kudenchuk PJ, Pierson DJ, Greene HL, Graham EL, Sears GK, Trobaugh GB. Prospective evaluation of amiodarone toxicity. Chest 1984;86:541-8.

11 Adams GD, Kehoe R, Lesch M, Glassroth J. Amiodaroneinduced pneumonitis: assessment of risk factors and induced pneumonitis: assessment of risk facto

12 Magro SA, Clinton PE, Wheeler SH, Krafchek J, Lin H, Wyndham C. Amiodarone pulmonary toxicity: prospective evaluation of serial pulmonary function tests. $\mathrm{J} \mathrm{Am}$ Coll Cardiol 1988;12:781-8.

13 Akoun GM, Milleron BJ, Gauthier-Rahman S, Mayaud Ch M. Amiodarone-induced hypersensitivity pneumonitis. Evidence of immunological cell-mediated mechanism. Chest 1984;85:133-5.

14 Israel-Biet D, Venet A, Caubarrère I, et al. Bronchoalveolar lavage in amiodarone pneumonitis. Cellular abnormalities and their relevance to pathogenesis. Chest 1987;91: 214-20.

15 Crystal RG, Gadek JE, Ferrans VJ, Fulmer JD, Line BR, Hunninghake GW. Interstitial lung disease: current concepts of pathogenesis, staging and therapy. Am J Med cepts of pathogen

16 Olsen T, Laurberg $P$, Weeke J. Low serum triiodothyronine and high serum reverse triiodothyronine in old age: an effect of disease not age. J Clin Endocrinol Metab 1978; 47:1111-5.

17 Sanz G, Castañer A, Betriu A, et al. Determinants of prognosis in survivors of myocardial infarction. A prospective clinical angiographic study. $N$ Engl $J$ Med
1982;306:1065-70.

18 Ferris GB. Epidemiology standardization project. Am Rev Respir Dis 1978;118 (suppl 2):55-110.

19 International Labour Office and Union Internationale Contre le Cancer. International classification of radiographs of pneumoconiosis. Geneva: International Labour Office, 1980. (Occupational Safety and Health Series, No 22.)

20 Heras M, Roca J, Sanz G, et al. Alteraciones subclinicas producidas por el tratamiento prolongado con amioproducidas por el tratamiento prolon
darona. Rev Esp Cardiol 1987;40:44-50.

21 Roca J, Sanchis J, Agusti-Vidal A, et al. Spirometric reference values from a mediterranean population. Bull reference values from a mediterranean
Eur Physiopathol Respir 1986;22:217-24.

22 Roca J, Rodriguez-Roisin R, Cobo E, Burgos F, Pérez J, Clausen JL. Single-breath carbon monoxide diffusing capacity $\left(\mathrm{TL}_{\infty}\right)$ prediction equations for a mediterranean population. Am Rev Respir Dis 1990;141:1026-32.

23 Goldman L, Mashimoto B, Cook F, Loscalzo A. Comparative reproducibility and validity of systems for assessing cardiovascular functional class. Advantages of a new specific activity scale. Circulation 1981;64:1227-34.

24 Xaubet A, Roca J, Rodriguez-Roisin R, et al. Bronchoalveolar lavage cellular analysis and gallium lung scan in the assessment of patients with amiodarone-induced the assessment of patients with amiodar.

25 Rotmensch $\mathrm{HH}$, Belhassen B, Swanson BN, et al. Steadystate serum amiodarone concentrations: relationships with antiarrhythmic efficacy and toxicity. Ann Intern Med 1984;101:462-9.

26 Martin WJ II, Howard DM. Amiodarone-induced lung toxicity. In vitro evidence for the direct toxicity of the drug. Am J Pathol 1985;120:344-50.

\title{
Adventitia
}

\section{Bungalow hospital and coral reef}

Saddened by the prospect of rapid dementia following compulsory retirement, I applied without success to a well known charity for work in the third world, possibly in starving East Africa. But within a few days, wheels having clearly worked within wheels, a telephone call came from the Overseas Development Administration, an organisation of which I then knew little. A pleasant interview followed with the senior medical adviser, the redoubtable Dr Penny Key, herself a veteran of several years' single handed practice in the depths of the jungles of Papua New Guinea. I arrived as temporary physician at Honiara, Guadalcanal, capital of the Solomon Islands, within a month.

The geographical surroundings were glorious, in particular the vast high vermilion and indigo cumulus in the evening sky. My quality of life was further enhanced by a heavily populated coral reef in the crystal clear sea, some 20 paces from my quarters.

The work, in a bungalow hospital with basic facilities, was caring for mainly young patients with treatable infective illnesses-sepsis, malaria, and tuberculous infection in roughly equal mix, with a scattering of leprosy. The medical department had been for some months under the sole care of an ethnic Chinese fifth year undergraduate from Melbourne, who was understandably showing signs of stress. Nursing care by locally trained women was excellent and very practical, and highly competent laboratory technicians were very supportive in the absence of a pathologist. Few people live long enough to develop degenerative disease, and ischaemic heart disease was absent, save for the case of Billy Bennett.

This delightful man had a unique record of personal valour in clandestine wartime jungle operations, his particular skills being with the dagger and the hand grenade. He specialised in the immediate burial of the remains down to the last button, so that the regular disap- demoralising to the enemy. His part in the delivery of intelligence to clandestine radio stations in the mountains by native runners, who might cover 30 miles in a night, contributed substantially to military successes in the area. Sadly he was of mixed New Zealand and Melanesian parentage, and thus inherited the genetic makeup which led to his sudden death from cardiac infarction.

Pidgin English was a source of delight, though it was not easy to acquire fluency. I fell in with an Australian naval padre who went round visiting the villages in a helicopter, known locally, and affectionately, as the "bigfellah mixmaster blong God"-one of many fine examples of the genre. Interestingly, the Service handout on tropical diseases, describing malaria, says ". . . the patient becomes hot and dry. He may vomit a lot and become delicious...,", which seems appropriate in a country that in the past was said to incline at times to cannibalism.

Refreshingly, carcinoma of the bronchus was also virtually absent, my only case being the chief of a hill village who presented with advanced and distressing superior vena caval obstruction from an adenocarcinoma in the right upper lobe. On being told that the only treatment available was chemotherapy, likely to have unpleasant side effects and to be of doubtful benefit, he declined and asked with deep courtesy whether he might, without causing offence, return home to seek the help of the village shaman. I visited his village a couple of months later, on the occasion of a pig feast for the opening of a long house for the local church, and was invited to his home, where I was warmly welcomed. Squatting on the earth floor of his grass hut, I was able to observe that the congested superficial veins had disappeared and that the facial oedema was strikingly reduced. His equanimity was complete. I came home with an enhanced sense of humility with regard to Western medicine.-JOHN EDGE 